\title{
TENTH ANNUAL MAY BIRD CENSUS REGINA DISTRICT
}

On Saturday, May 16, 36 persons counted a total of 134 species and 17,634 individuals in the Regina area. The number of species (134) was disappointing as ideal weather conditions prevailed during the day. However, the weather had been quite cool the previous week, with a $3^{\prime \prime}$ snowfall on Monday, and this might account for some of the species missing. The weather for the count day was mostly sunny and warm, winds light S.W. in the morning and brisk and westerly in the afternoon; temperature ranged between $42^{\circ}$ and $78^{\circ}$.

Species list (1969 numbers in brackets) :

Red-necked Grebe 1 (0); Horned Grebe 20 (18); Eared Grebe 8 (62); Western Grebe 4 (24); Great Blue Heron 1 (0); Black-crowned Night Heron 1 (4); American Bittern 1 (1); Mute Swan 2 (5) ; Whistling Swan 537 (10) ; Canada Goose 261 + 6 goslings (340); Mallard 977 (301); Gadwall 33 (30); Pintail 613 (157); Green-winged Teal 6 (13); Bluewinged Teal 83 (77); Cinnamon Teal 2 (0) ; American Widgeon 70 (52); Shoveler 432 (77) ; Redhead 28 (26); Canvasback 60 (63); Lesser Scaup 173 (130); Bufflehead 6 (7) ; Ruddy Duck 9 (34); Goshawk 1 (0); Redtailed Hawk 2 (2) ; Swainson's Hawk 14 (9); Marsh Hawk 42 (7); Pigeon Hawk 1 (0); Sparrow Hawk 1 (1); Gray Partridge 4 (3); Sora 31 (7); American Coot 170 (39); Killdeer 60 (84) ; Spotted Sandpiper 5 (22) ; Solitary Sandpiper 21 (2); Willet 34 (22); Greater Yellowlegs 2 (2) ; Lesser Yellowlegs 12 (13); Pectoral Sandpiper 148 (64); White-rumped Sandpiper 22 (0); Baird's Sandpiper 61 (78) ; Least Sandpiper 123 (13); Short-billed Dowitcher 1 (9) ; Longbilled Dowitcher $9(0)$; Stilt Sandpiper $3(0)$; Semipalmated Sandpiper 50 (28); Marbled Godwit 12 (7); American Avocet 71 (62); Wilson's Phalarope 22 (27); Northern Phalarope 2 (21); Ring-billed Gull 131
(78) ; Franklin's Gull 22 (10) ; Common Tern 14 (43); Black Tern 20 (20) ; Rock Dove 56 (81) ; Mourning Dove 45 (62); Black-billed Cuckoo 1 (0) ; Great Horned Owl $2+3$ young (5) ; Burrowing Owl 4 (2) ; Longeared Owl 1 (1); Short-eared Owl 30 (2) ; Belted Kingfisher 1 (4); Yellowshafted Flicker 45 (38); Yellowbellied Sapsucker 6 (2) ; Downy Woodpecker 1 (1); Eastern Kingbird 11 (16) ; Western Kingbird 30 (55) ; Eastern Phoebe 2 (5); Yellow-bellied Flycatcher $1(0)$; Traill's Flycatcher $4(0)$; Least Flycatcher $22(63)$; Olivesided Flycatcher 1 (2); Horned Lark 367 (415); Tree Swallow 55 (139); Bank Swallow 1 (21); Barn Swallow 16 (86); Purple Martin 16 (29); Black-billed Magpie 36 (42) ; Common Crow 121 (102); Catbird 1 (4); Brown Thrasher 3 (34); Robin 188 (160) ; Hermit Thrush 1 (2) ; Swainson's Thrush 347 (81) ; Gray-cheeked Thrush 181 (52); Veery 3 (1); Rubycrowned Kinglet 1 (2) ; Water Pipit 1 (0) ; Sprague's Pipit 2 (2) ; Loggerhead Shrike 52 (21); Starling 8 (42); Solitary Vireo 4 (2); Warbling Vireo 1 (0); Black-and-white Warbler 5 (9); Tennessee Warbler 7 (9); Orange-crowned Warbler 42 (11); Yellow Warbler 34 (45); Myrtle Warbler 171 (52) ; Blackpoll Warbler 13 (9) ; Palm Warbler 3 (2) ; Ovenbird 8 (3); Northern Waterthrush 15 (9); Yellowthroat 1 (4); House Sparrow 53 (457); Western Meadowlark 146 (249); Yellow-headed Blackbird 101 (53); Red-winged Blackbird 319 (545) ; Baltimore Oriole 20 (15); Rusty Blackbird 27 (2) ; Brewer's Blackbird 390 (226) ; Common Grackle 153 (136); Brown-headed Cowbird 103 (141) ; Rose-breasted Grosbeak 19 (27); Purple Finch 4 (20); Pine Grosbeak $3(0)$; Pine Siskin $6(0)$; White-winged Crossbill 6 (0) ; Rufoussided Towhee 6 (3) ; Lark Bunting 2 (13); Savannah Sparrow 30 (17); Vesper Sparrow 45 (42) ; Slate-colored Junco 1 (0); Chipping Sparrow 81 
(52); Clay-colored Sparrow 100 (118) ; Harris' Sparrow 67 (108); White-crowned Sparrow 81 (93); White-throated Sparrow 184 (90); Fox Sparrow 2 (2) ; Lincoln's Sparrow 74 (18) ; Song Sparrow 12 (10); McCown's Longspur 4 (82) ; Lapland Longspur 7816 (1252); Chestnutcollared Longspur 886 (124); Snow Bunting 1 (1).

Total Species, 134. Individuals 17,634. Participants: Jack Bailey, Jessie Bailey, Al Binnie, Betty Binnie, Greg
Bobbitt, Bill Brownlee, Frances Churchill, Nancy Coppin, Lynne Cross, Iola Crouse, George Dodd, Lucy Eley, Elmer Fox, Pearl Guest, Florence Hailstone, Bernie Haysom, Keith Haysom, Linda Hebert, Mrs. M. Horn, Gwen Jones, Harold Jowsey, Harriet Jowsey, Jim Jowsey, Shirley Jowsey, Helen Keay, Ferne Lawrence, Betty MacGregor, Colin McConnell, Helen Morrison, Joan Powell, Connie Pratt, Joe Roberts, Mrs. G. Smith, Mrs. Sykes, Charles Thacker, Dan Walker. Compiled by $A l$ and Betty Binnie.

\section{BLACK-CHINNED HUMMINGBIRD REPORTED AT REGINA}

\section{by Shirley Jowsey and J. R. Jowsey, 2635 19th Ave., Regina}

Hummingbird arrivals before June 1 are not unusual here in Kegina, but the sight of a hummingbird resting on a branch of our crabapple tree at noon on June 1,1970 was unusual enough to alert us to examine the bird closely. The bird was sitting in a position where we could observe it through the window of the house without alarming it, even though it was only seven feet from us. As it turned to face us, we noticed the absence of the bright ruby throat patch which we had expected to see, since the Rubythroated Hummingbird is the species likely to be observed in Regina.

Subsequent examinations of this bird on its return visits to the crabapple tree that day allowed us to observe all the field marks of the male Blackchinned Hummingbird. The main throat patch was distinctly black, as observed in several types of lighting, and the violet area below the black throat patch was clearly seen on two occasions.

In addition to the male hummingbird described above, we observed a female hummingbird several times on the evening of June 1. Since females of Blackchinned and Ruby-throated hummingbirds are similar in plumage patterns, we cannot be certain that the female was also a Black-chinned Hummingbird.

Unfortunately, we were not able to show the bird to another observer that day to get a verification of our identification, and no sightings of the pair were made on the following day. The Black-chinned Hummingbird is not on the provincial checking-list for Saskatchewan, and, to the best of our knowledge, it has not previously been reported in the province. W. Earl Godfrey in The Birds of Canada (1966) describes its status in Canada as that of a "scarce summer visitant, probably breeding, in southern interior British Columbia (Chilliwack east to Creston, north to Grindrod)." Its distribution is more general to the south of the border, and the A.O.U. Check-List (1957) gives it as breeding "from southwestern British Columbia and northwestern Montana (Columbia Falls) south through western Montana, central Idaho, western Colorado, New Mexico, and south-central and southwestern Texas... to northern Baja, California . . . Sonora, and extreme southwestern Chihuahua." No records of its occurrence in Alberta are cited in Salt and Wilks, The Birds of Alberta (rev. ed., 1966).

Local weather conditions did not suggest a reason for the sighting of this rare bird in Regina, but larger weather disturbances may have pressed a pair eastward from their normal migration route to Montana and southern British Columbia. 